\title{
Genetic Analysis of Diallel Crosses in Wheat under Drought and Normal Irrigation Treatments
}

Hoda R. El-Safy, M.EL.M. EL-Badawy, S. A. H. Allam and A.A.A. El Hosary

Agronomy Dep, Fac. of Agric, Moshtohor, Egypt

Corresponding Author: ahmed.alhossary@fagr.bu.edu.eg

\begin{abstract}
Seven bread wheat genotypes were crossed in a7x7half diallel scheme in 2017/2018.Parents and their 21 F1 crosses were evaluated under normal and stress conditions during 2018/2019 in two field experiments. The results of analysis of variance were significant for all studied traits. The highest mean values were detected by parents P1, P1,P2, P3,P2 and p2 for plant height, spike length, No of spikes/ plant, 1000-kernel weight, biological yield/ plant and grain yield/ plant, respectively. While, the highest mean values were recorded with crosses P3xP5 for biological yield/ plant and grain yield / plant. Mean squares for both general (GCA) and specific (SCA) combining ability estimates were highly significant for most studied traits. The ratios between GCA and SCA exceeded the unity for all studied traits, except biological yield/ plant under drought, revealing that additive and additive $\mathrm{x}$ additive types of gene action are more important than non-additive gene action in controlling these traits. P6 exhibited positive and significant ĝi effects for biological yield/ plant. P7 gave positive and significant combiner for spike length, No of spikes/ plant and grain yield/ plant. The highest desirable SCA effects were obtained with $\mathrm{P}_{1} \times \mathrm{P}_{6}, \mathrm{P}_{1} \times \mathrm{P}_{7}, \mathrm{P}_{2} \times \mathrm{P}_{7}, \mathrm{P}_{3} \times \mathrm{P}_{5}$ and $\mathrm{P}_{4} \times \mathrm{P}_{7}$ for grain yield/ plant which exhibited significant and positive sij effects
\end{abstract}

${ }^{1}$ Foreign Agricultural Service / USDA Office of Global Analysis

http://www.pecad.fas.usda.gov

( 1 metric ton per hectare $=100$ grams per square meter, 1 hectare $($ ha $)=10,000$ square meters $)$.

Key words: Wheat, combining ability, drought stress, GCA and SCA.

\section{Introduction}

Wheat (Triticumaestivum L.) is the major cereal crop in Egypt as well as several other countries. World average cultivated area of wheat reached $221.73^{1}$ million hectares in 2017 ; the total production was $751.36^{*}$ million metric tons, with an average productivity of $3.39 *$ metric tons per hectare. Egypt grew in $2017,1.25 *$ million hectares and produced $8.10^{*}$ million metric tons of grains, with an average yield of $6.43 *$ metric tons per hectare. With increasing population, it could hardly satisfy only $55 \%$ of local requirements. The increasing gap between production and consumption necessitates increasing wheat production in Egypt. Increasing the productivity of wheat through an efficient breading program to overcome this problem.

Drought stresses can occur at any stage of plant growth and development, thus illustrating the dynamic nature of crop plants and their productivity. Drought is the most widespread and limiting crop productivity. There are definitions of drought, which include precipitation, evapo-transpiration, potential evapotranspiration, temperature, humidity and other factors individually or in combination (Prasad et al.,
1998). Also selection for genotypes with increased productivity in drought environments has been an important of many plant breeding programs, the biological basis for drought tolerance is still poorly understood.

Knowledge of genetic behavior and type of gene action controlling target traits is a basic principle for designing an appropriate breeding procedure for the purpose of genetic improvement(Farshadfar et al., 2008 and Nouri et al., 2011). The diallel cross designs are frequently used in plant breeding research to obtain information about genetic properties of parental lines or estimates of general combining ability (GCA), specific combining ability (SCA) and heritability (Baker, 1978; ELMaghraby et al., 2005 and Iqbal et al., 2007). In addition, the diallel cross technique was reported to provide early information on the genetic behavior of these attributes in the first generation (Chowdhry et al., 1992 and Topal et al., 2004). To establish a sound basis for any breeding program aimed at achieving high yield, breeders must have information on the nature of combining ability of parents, their behavior and hybrid combinations performance (Chawla and Gupta, 1984). Combining ability analysis helps in the identification of parents with high GCA and parental combinations with high SCA. Based on combining ability analysis of different characters, higher SCA values refer to dominance gene effects and higher GCA effects indicate a 
greater role of additive gene effects controlling the characters (Sprague and Tatum, 1942). The main objectives of the present investigation were to: 1) Identify superior parents and cross combinations from $7 \times 7$ diallel cross of bread wheat parental genotypes for drought avoidance and tolerance traits. 2) estimate the magnitude of heterosis, GCA and SCA to improve wheat productivity under drought condition.

\section{Materials and Methods}

This investigation was carried out at the Experiment, Research Station of Moshtohor Faculty of Agriculture, Benha University, Kalubia Governorate, Egypt during the two successive seasons 2017/2018 and 2018/2019. Seven genotypes of wheat representing a wide range of diversity for several agronomic characters and drought resistance measurements were selected for the study. The names, pedigree and origin of these varieties are presented in Table (1).

Table 1. The code no, name, pedigree and source of the studied parental varieties and lines.

\begin{tabular}{|c|c|c|c|}
\hline NO & Entry name & Pedigree & Source \\
\hline 1 & YakoraRojo & $\begin{array}{l}\text { Ciano 67/Sonora } 6411 \text { Klien } \\
\text { Rendidor/3/1L815626Y-2M-1Y-0M-302M }\end{array}$ & CIMMYT \\
\hline 2 & M 137 & MILAN \S7145 \\
OAPYMex & CIMMY \\
\hline 3 & Gemmiza12 & $\begin{array}{l}\text { OTUS/3/SARA/THB//VEE (CMSS97YOO227 S-5Y-010M-010Y- 010M-2Y - } \\
\text { 1M-0Y- OGM) }\end{array}$ & Egypt \\
\hline 4 & Sakha 94 & $\begin{array}{l}\text { PASTOR // SITE / MO /3/ CHEN / AEGILOPS SQUARROSA (TAUS) // } \\
\text { BCN /4/ WBLL1 (CMSA01Y00158S-040P0Y-040M-030ZTM-040SY-26M- } \\
\text { 0Y-0SY-0S). }\end{array}$ & Egypt \\
\hline 5 & Gemmiza 9 & ALD"S"/HUAC"S"//CMH74A.630/5X & Egypt \\
\hline 6 & Sids 12 & $\begin{array}{l}\text { BUC//7C/ALD/5/MAYA74/ON//1160.147/3/BB/GLL/4/CHAT"S"/6/MAYA/ } \\
\text { VUL//CMH74A.630/4*SX SD7096-4SD-1SD-1SD-0SD }\end{array}$ & Egypt \\
\hline 7 & Sids 13 & $\begin{array}{l}\text { Kauz "s" // Tsi / Snb"s" } \\
\text { ICW94-0375-4AP-2AP-030AP-0APS-3AP-0APA-050AP-0AP-0SD }\end{array}$ & Egypt \\
\hline
\end{tabular}

The line No 2 was developed in Department of Agronomy, Fac. of Agic. At Moshtohor, Banha Univ. by Dr. A.A.A. El Hosary.

The parents were crossed in a $7 \times 7$ diallel cross excluding reciprocals in 2017/2018 growing season giving a total of twenty-one crosses. In 2018/2019 two experiments using randomized complete block design with three replications were carried out. Each experiment contained the seven parents and their resulting $21 \mathrm{~F}_{1}$ 's. The sowing date was on $4^{\text {th }} \mathrm{Dec}$. 2018. The first experiment was irrigated only once after planting irrigation and the second one was normally irrigated five irrigations. Plots of parents and F1's consisted of one row, 3 m-long, with spacing of $30 \mathrm{~cm}$ between rows and $20 \mathrm{~cm}$ between plants. The dry method of planting was used in this study. The other cultural practices of growing wheat were practiced. The amounts of total rainfall during the evaluating season were recorded in Table (2).Ten guarded plants from parents and the $F_{1}$ 's were selected randomly from each plot for recording observations on different characters. The characters studied were, Plant height $(\mathrm{cm})$, spike length $(\mathrm{cm})$, No .of spikes /plant, 1000- kernel weight (g), biological yield/ plant and grain yield/ plant (g).

Heterosis for each trait was computed as parents $v s$. crosses sum of squares was obtained by partitioning the genotypes sum of square to its components. Analysis of variance was conducted as outlined by Steel and Torrie (1980) for all characters. The analysis of GCA and SCA was done following the procedure given by Griffing (1956) using Method II Model I. The combined analysis of the two experiments was carried out whenever homogeneity of mean squares was detected (Gomez and Gomez 1984).

Table 2. Monthly averages of temperature, relative humidity (R.H.) and total rain fall during 2018/2019 season at Kalubia (Moshtohor).

\begin{tabular}{|c|c|c|c|c|}
\hline \multirow{2}{*}{ Months } & \multicolumn{2}{|c|}{ Temperature $\mathbf{C}$} & \multirow{2}{*}{$\begin{array}{l}\text { R.H. } \\
(\%)\end{array}$} & \multirow{2}{*}{$\begin{array}{c}\text { Rain fall } \\
\text { mm/month }\end{array}$} \\
\hline & Min. & Max. & & \\
\hline Dec.2018 & 9.2 & 19.7 & 51.3 & 0.5 \\
\hline Jan.2019 & 6.1 & 17.7 & 55.9 & 1.6 \\
\hline Feb.2019 & 7.8 & 20.4 & 47.2 & 0.8 \\
\hline Mar.2019 & 11.4 & 25.8 & 37.3 & 0.4 \\
\hline Apr.2019 & 14.4 & 29.1 & 38.9 & 0.3 \\
\hline May.2019 & 19.0 & 34.5 & 32.1 & ---- \\
\hline
\end{tabular}




\section{Results and Discussion}

Analysis of variance for yield and its components under drought and normal irrigation and combined analysis across the mention environments are presented in Table 3. Results indicated that mean squares due to irrigation treatments (Environments) were highly significant for all studied traits indicating overall differences between the two environments of study.

Genotypes mean squares were highly significant for all studied traits except, no of spikelets/ spike, indicating wide diversity between all genotypes used in this work. Moreover, significant mean squares between genotypes and environment interaction were detected for all studied traits. This result indicated that genotypes responded differently to different environments for the mention traits.

Mean squares due to parents were highly significant for all traits in drought stress, normal irrigation and combined across them, indicating that these parents are differently in the significant for these traits. Moreover, mean squares due to the interaction between parents and environments were significant for all studied traits. Such result indicated that wheat parents responded differently to stress and non-stress conditions for these traits.

Table 3. Mean squares for yield and its components under drought stress condition and normal irrigation as well as the combined over them.

\begin{tabular}{|c|c|c|c|c|c|c|c|}
\hline S.O.V. & Df & $\begin{array}{c}\text { Plant height } \\
(\mathrm{cm})\end{array}$ & $\begin{array}{l}\text { Spike } \\
\text { length }(\mathrm{cm})\end{array}$ & $\begin{array}{c}\text { No. of spikes } \\
\text { /plant }\end{array}$ & $\begin{array}{c}1000 \text { kernel } \\
\text { weight }(\mathrm{g})\end{array}$ & $\begin{array}{c}\text { Biological } \\
\text { yield/plant (g) }\end{array}$ & $\begin{array}{c}\text { Grain } \\
\text { yield/plant (g) }\end{array}$ \\
\hline \multicolumn{8}{|c|}{ Drought environment } \\
\hline Rep & 2 & 3.67 & $7.75^{*}$ & 1.55 & $3.43 * *$ & $175.00 * *$ & $35.36 *$ \\
\hline $\begin{array}{l}\text { Genoty } \\
\text { pes }(G)\end{array}$ & 27 & $85.14 * *$ & $6.94 *$ & $217.62 * *$ & $1.314 * *$ & $21627.32 * *$ & $934.72 * *$ \\
\hline $\begin{array}{l}\text { Parent } \\
\text { (P) }\end{array}$ & 6 & $156.85^{* *}$ & $17.05 * *$ & $345.40 * *$ & $1.61 * *$ & $5709.43 * *$ & $628.53 * *$ \\
\hline $\begin{array}{l}\text { Cross ( } \\
\text { C) }\end{array}$ & 20 & $67.47 * *$ & $4.15^{*}$ & $176.39 * *$ & $1.28 * *$ & $27356.53 * *$ & $1069.98 * *$ \\
\hline P vs C. & 1 & $8.33 *$ & 1.92 & $275.42 * *$ & $3.22 * *$ & $2550.47 * *$ & $66.54 * *$ \\
\hline Error & 54 & 4.35 & 1.97 & 4.94 & 0.044 & 56.48 & 16.38 \\
\hline \multicolumn{8}{|c|}{ Normal environment } \\
\hline Rep & 2 & $25.50 * *$ & 0.75 & 0.05 & $1.87 * *$ & 120.23 & $109.34 * *$ \\
\hline $\begin{array}{l}\text { Genoty } \\
\text { pes (G) }\end{array}$ & 27 & $89.38 * *$ & $8.71 *$ & $160.54 * *$ & $0.62 *$ & $8708.39 * *$ & $1897.95^{* *}$ \\
\hline $\begin{array}{l}\text { Parent } \\
\text { (P) }\end{array}$ & 6 & $119.94 * *$ & $18.27 * *$ & $49.09 * *$ & $0.69 *$ & $2904.24 * *$ & $36.46 * *$ \\
\hline $\begin{array}{l}\text { Cross ( } \\
\text { C) }\end{array}$ & 20 & $84.67 * *$ & $5.70 *$ & $194.86^{* *}$ & $0.59 *$ & $10057.67 * *$ & $2486.2 * *$ \\
\hline P vs C. & 1 & 0.22 & $11.57 * *$ & $148.92 * *$ & $0.68 *$ & $16547.54 * *$ & $1301.40 * *$ \\
\hline Error & 54 & 4.13 & 1.90 & 6.25 & 0.62 & 62.64 & 13.54 \\
\hline \multicolumn{8}{|c|}{ Combined analysis } \\
\hline $\begin{array}{l}\text { Irrigati } \\
\text { on (I) }\end{array}$ & 1 & 0.12 & $3.43 *$ & $2936.83 * *$ & $0.67 * *$ & $173829.91 * *$ & $11092.99 * *$ \\
\hline Rep/ I & 4 & $14 . .57$ & $4.25 *$ & 0.80 & $2.65 * *$ & 147.61 & $72.35 *$ \\
\hline $\begin{array}{l}\text { Genoty } \\
\text { pes (G) }\end{array}$ & 27 & $73.69 * *$ & $9.30 * *$ & $209.67 * *$ & $0.91 * *$ & $18107.76 * *$ & $1093.39 * *$ \\
\hline $\begin{array}{l}\text { Parent } \\
\text { (P) }\end{array}$ & 6 & $166.26^{* *}$ & $22.43 * *$ & $301.44 * *$ & $0.98 * *$ & $6291.80 * *$ & $429.24 * *$ \\
\hline $\begin{array}{l}\text { Cross ( } \\
\text { C) }\end{array}$ & 20 & $49.33 * *$ & $5.25 *$ & $192.14^{* *}$ & $0.77 * *$ & $21755.67 * *$ & $1327.82^{* *}$ \\
\hline P vs C. & 1 & 5.63 & $11.46 * *$ & 6.65 & $3.43 * *$ & $16045.47 * *$ & $389.69 * *$ \\
\hline $\mathbf{G} \times \mathbf{I}$ & 27 & $100.83 * *$ & $6.35 *$ & $168.49 * *$ & $1.02 *$ & $12227.95 * *$ & $1739.28 * *$ \\
\hline$p \times I$ & 6 & $110.53^{* *}$ & $12.89 * *$ & $92.05 * *$ & $1.33 *$ & $2321.86 * *$ & $235.75 * *$ \\
\hline $\mathrm{C} \times \mathrm{I}$ & 20 & $102.81 * *$ & $4.61 *$ & $179.11 * *$ & $0.95 *$ & $15658.54 * *$ & $2228.39 * *$ \\
\hline $\begin{array}{l}\text { P.vs.C } \\
\times \mathrm{I}\end{array}$ & 1 & 2.92 & 2.03 & $414.69 * *$ & 0.47 & $3052.54 * *$ & $978.25^{* *}$ \\
\hline Error & $\begin{array}{c}10 \\
8 \\
\end{array}$ & 4.24 & 1.94 & 5.59 & 0.33 & 59.56 & 14.96 \\
\hline
\end{tabular}

$*$ and $* *$ significant at 0.05 and 0.01 levels of probability, respectively.

\section{Mean performance}

Results in Table (4) showed the average of plant height, yield and its components traits at the combined across irrigation treatments. It's clear that the parental line $\left(\mathrm{P}_{1}\right)$ gave the highest mean value for spike length and 100-kernel weight. On the other hand, P2 was the highest parent for No of spikes/ plant, biological yield and grain yield/ plant. The 
parent P6 was the shortest parent in this study. Plant height for crosses ranged from $98.90 \mathrm{~cm}(\mathrm{P} 3 \times \mathrm{P} 6)$ to $108.5 \mathrm{~cm}$ (P1xP6). Moreover, the crosses P1xP5, $\mathrm{P} 4 \mathrm{xP} 7$ and $\mathrm{P} 1 \mathrm{xP} 2$ did not differ significantly than the tallest hybrid P1xP6. Some farmers usually prefer higher plant due to the high price of hay. On the other hand, this plant must be given high yield for grain and behave resistant to lodging. The highest parents mean value for spike length (14.83) was detected for P1xP6. However, eight crosses P1xP5,
$\mathrm{P} 1 \times \mathrm{P} 7, \mathrm{P} 2 \times \mathrm{P} 4, \mathrm{P} 2 \times \mathrm{P} 8, \mathrm{P} 3 \times \mathrm{P} 4, \mathrm{P} 4 \mathrm{xP} 5, \mathrm{P} 4 \times \mathrm{P} 7$ and $\mathrm{P} 6 \mathrm{xP} 7$ exhibited highest values for spike length. For No. of spike/ plant the cross $\mathrm{P} 5 \mathrm{xP7}$ give the highest number of spikes/ plant. Heavier 1000-kernel weight was detected by P1xP4.The cross P3xP5 exhibited the highest values for biological yield/ plant andgrain yield / plant.Therefore, this cross could be efficient for prospective wheat breeding programs aiming at improving wheat grain yield.

Table 4. Mean performance of the genotypes for yield and its components over the studied environments .

\begin{tabular}{|c|c|c|c|c|c|c|}
\hline Genotype & $\begin{array}{c}\text { plant height } \\
\text { (cm) }\end{array}$ & $\begin{array}{c}\text { spike } \\
\text { length }(\mathrm{cm})\end{array}$ & $\begin{array}{l}\text { No. of spikes } \\
\text { /plant }\end{array}$ & $\begin{array}{l}1000 \text { kernel } \\
\text { weight (g) }\end{array}$ & $\begin{array}{c}\text { Biological } \\
\text { yield/plant } \\
\text { (g) }\end{array}$ & $\begin{array}{c}\text { Grain } \\
\text { yield/plant } \\
\text { (g) }\end{array}$ \\
\hline $\mathrm{P} 1$ & 107.50 & 14.83 & 20.50 & 57.50 & 237.97 & 67.00 \\
\hline $\mathrm{P} 2$ & 103.50 & 13.33 & 43.07 & 54.17 & 316.38 & 88.07 \\
\hline P3 & 93.83 & 9.83 & 29.67 & 65.17 & 250.20 & 65.88 \\
\hline $\mathrm{P} 4$ & 101.17 & 12.50 & 24.60 & 54.83 & 312.00 & 61.22 \\
\hline P5 & 109.59 & 15.33 & 25.82 & 54.09 & 304.51 & 70.29 \\
\hline P6 & 98.90 & 11.50 & 28.78 & 54.55 & 308.34 & 71.51 \\
\hline P7 & 102.94 & 14.00 & 27.30 & 54.52 & 306.69 & 70.64 \\
\hline $1 \times 2$ & 106.00 & 13.67 & 22.67 & 52.33 & 240.23 & 71.17 \\
\hline $1 \times 3$ & 99.67 & 12.50 & 35.17 & 55.33 & 339.67 & 81.40 \\
\hline $1 \times 4$ & 99.67 & 13.17 & 25.23 & 59.00 & 340.62 & 68.67 \\
\hline $1 \times 5$ & 107.33 & 14.33 & 30.17 & 47.83 & 430.30 & 64.83 \\
\hline $1 \times 6$ & 108.50 & 14.83 & 24.17 & 57.50 & 430.00 & 98.33 \\
\hline $1 \times 7$ & 100.17 & 15.17 & 28.50 & 51.33 & 264.60 & 88.67 \\
\hline $2 \times 4$ & 104.50 & 14.00 & 27.00 & 51.00 & 255.87 & 76.00 \\
\hline $2 \times 5$ & 101.50 & 13.67 & 28.20 & 49.33 & 285.50 & 50.90 \\
\hline $2 \times 6$ & 104.33 & 12.83 & 33.83 & 51.00 & 327.42 & 88.67 \\
\hline $2 \times 7$ & 103.50 & 11.50 & 34.72 & 55.00 & 312.75 & 66.33 \\
\hline $2 \times 8$ & 101.50 & 14.50 & 33.33 & 44.17 & 300.40 & 77.13 \\
\hline $3 \times 4$ & 100.33 & 14.17 & 26.83 & 56.33 & 233.87 & 70.33 \\
\hline $3 \times 5$ & 103.17 & 13.00 & 30.33 & 55.33 & 451.80 & 117.92 \\
\hline $3 \times 6$ & 97.67 & 13.33 & 33.67 & 56.33 & 315.87 & 67.67 \\
\hline $3 \times 7$ & 103.50 & 13.00 & 22.00 & 48.50 & 259.83 & 51.75 \\
\hline $4 \times 5$ & 105.83 & 14.67 & 16.83 & 54.83 & 308.48 & 66.33 \\
\hline $4 \times 6$ & 101.00 & 13.17 & 21.60 & 52.33 & 258.03 & 67.13 \\
\hline $4 \times 7$ & 106.91 & 14.67 & 24.30 & 53.88 & 309.30 & 73.27 \\
\hline $5 \times 6$ & 103.01 & 13.00 & 22.95 & 54.17 & 303.72 & 70.58 \\
\hline $5 \times 7$ & 101.30 & 12.83 & 39.90 & 55.17 & 306.91 & 70.22 \\
\hline $6 \times 7$ & 101.76 & 14.67 & 26.16 & 54.50 & 307.07 & 70.37 \\
\hline L.S.D $5 \%$ & 2.35 & 1.59 & 2.70 & 1.32 & 8.82 & 4.42 \\
\hline L.S.D $1 \%$ & 3.12 & 2.11 & 3.58 & 1.75 & 11.70 & 5.86 \\
\hline
\end{tabular}

\section{Combining ability}

The analysis of variance for combining ability for plant height, spike length, number of spikes/ plant, 1000-kernel weight, biological yield, and grain yield/ plant,under drought treatment, normal irrigation and combined analysis is presented in Table 5.

General (GCA) and specific (SCA) combining ability mean squares were highly significant for all studied traits in both irrigations as well as combined analysis except for 1000-kernel weight drought and No of spikes/ plant and 1000-kernel weight under normal conditions. Such results indicated that both types of combining ability are important in the inheritance of these traits. Moreover, the ratios between GCA and SCA exceeded the unity for all studied traits, except biological yield/ plant under drought, revealing that additive and additive $\mathrm{x}$ additive types of gene action are more important than non-additive gene action in controlling these traits. The genetic variance was previously reported to be mostly due to additive effects for plant height by $\mathbf{E l}$ Hosaryet al (2009); for spikes/ plant by El Seidy 
and Hamada (1997), El Borhamy (2000) andGomaaet al (2014); for 1000-grain weight by EI Seidy and Hamada (1997) and El Borhamy (2000), and for grain yield/ plant by El Seidy and Hamada (1997), El Seidy and Hamada(2000),El Borhamy (2000), Abd El-Aty and Katta (2002), El Hosaryet al (2012) andGomaa et al (2014), Al Saadoon et al.( 2017), Al Saadoon et al.( 2018), ElHosary et al. (2019), Fathallah et al.. (2020) and Al-Tamimi et al. (2020).

The mean squares of the interaction between GCA, SCA and irrigation treatments were significant for all studied traits except both types of combining abilities x I for 1000-kernel weight and SCAxI at spike length and no of spike/ plant. Such result indicated that the additive and non-additive types of gene action differed significantly from one irrigation to another for these traits. Similar results were reported by El-Seidy and Hamada (1997),El-Seidy and Hamada (2000) Al Saadoon et al.( 2017), Al Saadoon et al.( 2018), El-Hosary et al. (2019), Fathallah et al.. (2020) and Al-Tamimi et al. (2020).

The ratio SCA $\mathrm{x}$ environment/ SCA was much higherthan that of GCA $\mathrm{x}$ irrigation/ GCA for plant height indicating that non-additive effects were much more influenced by environments than additive genetic one. However, the ratio of GCAx E/ GCA were high than SCAxE/SCA for biological yield and grain yield / plant, indicating additive was changed greater than non-additive for environment changing. Such results are in harmony with those obtained by El Hosary and Nour El Deen (2015), Al Saadoon et al.( 2017), Al Saadoon et al.( 2018), El-Hosary et al. (2019), Fathallah et al.. (2020 ) and AlTamimi et al. (2020).

Table 5. Combining abilitymean squares for yield and its components under normal irrigation and drought stress condition as well as the combined over them.

\begin{tabular}{|c|c|c|c|c|c|c|c|}
\hline S.O.V. & Df & $\begin{array}{c}\text { plant } \\
\text { height } \\
(\mathbf{c m})\end{array}$ & $\begin{array}{c}\text { spike } \\
\text { length }(\mathrm{cm})\end{array}$ & $\begin{array}{l}\text { No. of } \\
\text { spikes } \\
\text { /plant }\end{array}$ & $\begin{array}{c}1000 \\
\text { kernel } \\
\text { weight }(\mathrm{g})\end{array}$ & $\begin{array}{c}\text { Biological } \\
\text { yield/plant } \\
\text { (g) }\end{array}$ & $\begin{array}{c}\text { Grain } \\
\text { yield/plant } \\
\text { (g) }\end{array}$ \\
\hline \multicolumn{8}{|c|}{ Drought treatment } \\
\hline GCA & 6 & $66.18 * *$ & $4.06 * *$ & $2.51 * *$ & 0.52 & $4438.88 * *$ & $429.37 * *$ \\
\hline SCA & 21 & $17.58 * *$ & $1.81 *$ & $1.60 * *$ & 0.42 & $8000.60 * *$ & $277.92 * *$ \\
\hline Error & 54 & 1.45 & 0.66 & 0.40 & 0.35 & 18.83 & 5.46 \\
\hline GCA/SCA & & 3.76 & 2.24 & 1.57 & 1.25 & 0.55 & 1.54 \\
\hline \multicolumn{8}{|c|}{ Normal irrigation treatment } \\
\hline GCA & 6 & $42.80 * *$ & $1.90 *$ & 1.01 & 0.19 & $3179.44 * *$ & $676.96 * *$ \\
\hline $\mathrm{SCA}$ & 21 & $26.08 * *$ & $3.60 * *$ & 1.23 & 0.21 & $2823.75 * *$ & $619.99 * *$ \\
\hline Error & 54 & 1.38 & 0.63 & 0.48 & 0.54 & 20.88 & 4.51 \\
\hline GCA/SCA & & 1.64 & 1.33 & 0.82 & 0.89 & 1.13 & 1.09 \\
\hline \multicolumn{8}{|c|}{ Combined analysis } \\
\hline GCA & 6 & $54.91 * *$ & $5.71 * *$ & $3.03 * *$ & 0.46 & $4786.15 * *$ & $316.20 * *$ \\
\hline SCA & 21 & 15.90 & 2.35 & 1.12 & 0.26 & $6393.00 * *$ & $378.25 * *$ \\
\hline GCA $x \mathrm{~L}$ & 6 & $100.83 * *$ & $6.35 * *$ & $4.29 * *$ & 1.02 & $\begin{array}{c}12227.95 * \\
*\end{array}$ & $1739.28 * *$ \\
\hline SCA $\times$ L & 21 & $54.07 * *$ & 1.95 & 0.49 & 0.24 & $2832.17 * *$ & $790.13 *$ \\
\hline Error & 108 & 27.76 & 2.17 & 0.44 & 0.37 & $4431.36 * *$ & 519.65 \\
\hline GCA/SCA & & 1.41 & 0.65 & 0.69 & 0.44 & $19.85^{* *}$ & 4.99 \\
\hline $\begin{array}{l}\text { GCA x } \\
\text { L/GCA }\end{array}$ & & 1.84 & 1.11 & 1.41 & 2.20 & 2.55 & 5.50 \\
\hline $\begin{array}{l}\text { SCA x } \\
\text { L/SCA }\end{array}$ & & 3.40 & 0.83 & 0.43 & 0.94 & 0.44 & 2.09 \\
\hline
\end{tabular}

$* \mathrm{p}<0.05 ; * * \mathrm{p}<0.01$

General combing ability (GCA) effects

Test of homogeneity revealed the validity of the combined analysis for the data of the two irrigation treatments. The general combining ability effects $\hat{g}_{i}$ of each parent for all studied measurements at the combined analysis are presented in Table (6). Such results are being used to compare the average performance of each parent with other genotype and facilitate selection of parents for further improvement to drought resistance. Results indicate that the parental $\mathrm{P}_{1}$ gave desirable significant gi effects for plant height, spike length and biological yield/ plant and grain yield/ plant. $\mathrm{P}_{2}$ exhibited significant and positive ĝi effects for plant height andno of spikes/ plant. P3 gave useful significantĝi effects forNo of spikes/ plant, 1000-kernel weight, and grain yield/ plant. $\mathrm{P}_{5}$ seemed good general combiner for plant height, spike length and biological yield/ plant. P6 exhibited positive and significant ĝi effectsfor biological yield/ plant. P7 gave positive and significant combiner for spike length, No of spikes/ plant and grain yield/ plant. 
Table 6. Estimates of general combining ability effects for yield and its components at the combined analysis.

\begin{tabular}{|c|c|c|c|c|c|c|}
\hline Parent & $\begin{array}{c}\text { plant } \\
\text { height } \\
(\mathrm{cm})\end{array}$ & $\begin{array}{c}\text { spike } \\
\text { length }(\mathrm{cm} \\
)\end{array}$ & $\begin{array}{l}\text { No. of } \\
\text { spikes } \\
\text { /plant }\end{array}$ & $\begin{array}{c}1000 \text { kernel } \\
\text { weight }(g)\end{array}$ & $\begin{array}{c}\text { Biological } \\
\text { yield/plant (g) }\end{array}$ & $\begin{array}{c}\text { Grain } \\
\text { yield/plant } \\
\text { (g) }\end{array}$ \\
\hline P1 & $1.54 * *$ & $0.59 * *$ & $-2.00 * *$ & 0.07 & $6.55 * *$ & $5.55 * *$ \\
\hline $\mathbf{P 2}$ & $0.65^{* *}$ & -0.13 & $4.55^{* *}$ & $-0.23^{*}$ & $-11.93 * *$ & $-2.71 * *$ \\
\hline P3 & $-2.88 * *$ & $-0.93 * *$ & $1.04 * *$ & $0.24 * *$ & $-11.67 * *$ & $2.84 * *$ \\
\hline P4 & $-0.54 * *$ & 0.06 & $-3.64 * *$ & 0.04 & $-11.39 * *$ & $-7.48 * *$ \\
\hline P5 & $2.41 * *$ & $0.37 * *$ & 0.08 & -0.05 & $30.58 * *$ & 0.39 \\
\hline P6 & $-1.02 * *$ & $-0.49 * *$ & $-0.46^{*}$ & 0.08 & $9.08 * *$ & -0.33 \\
\hline P7 & -0.16 & $0.54 * *$ & $0.43 *$ & -0.16 & $-11.20 * *$ & $1.73 * *$ \\
\hline L.S.D $(0.05)$ gi & 0.31 & 0.21 & 0.36 & 0.17 & 1.167 & 0.58 \\
\hline L.S.D(0.01) gi & 0.42 & 0.29 & 0.49 & 0.24 & 1.58 & 0.79 \\
\hline $\begin{array}{l}\text { L.S.D(0.05) } \\
\text { gi-gj }\end{array}$ & 0.55 & 0.37 & 0.63 & 0.31 & 2.05 & 1.031 \\
\hline $\begin{array}{l}\text { L.S.D(0.01) } \\
\text { gi-gj }\end{array}$ & 0.75 & 0.50 & 0.86 & 0.42 & 2.79 & 1.40 \\
\hline
\end{tabular}

Specific combining ability (SCA) effects

Specific combining ability effects $\hat{S}_{i j}$ for the $\mathrm{F}_{1}$ crosses for the studied traits in the combined analysis are presented in (Table 7).

For plant height, four crosses expressed significant and positive sij effects. Moreover, the cross $\mathrm{P}_{1} \times \mathrm{P}_{6}, \mathrm{P}_{2} \times \mathrm{P}_{3}, \mathrm{P}_{3} \times \mathrm{P}_{7}$ and $\mathrm{P}_{4} \times \mathrm{P}_{7}$ gave the positive $\hat{\text { sij }}$ effects for plant height. However, three crosses i.e. P1xP4, P1xP7 and P5xP7 gave significant and negative $\hat{\mathrm{s}} \mathrm{ij}$ effects for the mention trait. For spike length, fourcrosses $\left(\mathrm{P}_{1} \times \mathrm{P}_{6}, \mathrm{P}_{2} \times \mathrm{P}_{3}, \mathrm{P}_{3}\right.$ $\mathrm{x} \mathrm{P}_{6}$ and $\mathrm{P}_{5} \mathrm{x}_{\mathrm{P}}$ ) expressed significant and positive $\hat{\mathrm{s}} \mathrm{ij}$ effects. For number of spikes/ plant, three crosses $\left(\mathrm{P}_{1} \times \mathrm{P}_{3}, \mathrm{P}_{1} \times \mathrm{P}_{5}\right.$ and $\left.\mathrm{P}_{3} \times \mathrm{P}_{6}\right)$ expressed significant and positive sij effects. However, the best cross $\mathrm{P}_{5} \mathrm{x} \mathrm{P}_{7}$ gave sij effects $\left(11.28^{* *}\right)$ being the highest one in this trait. Regarding to biological yield/ plant, eight crosses i. e. P1xP3, P1xP4, P1xP5, P1xP6, P2xP7, $\mathrm{P} 3 \times \mathrm{P} 5, \mathrm{P} 3 \mathrm{xP} 6$ and $\mathrm{P} 4 \times \mathrm{P} 7$ exhibited significant and positive $\hat{s i j}$ effects. Five crosses combinations exhibited significant and positive sij effects for grain yield/ plant. The best positive sij effects were the crosses $\mathrm{P}_{1} \times \mathrm{P}_{6}, \mathrm{P}_{1} \times \mathrm{P}_{7}, \mathrm{P}_{2} \times \mathrm{P}_{7}, \mathrm{P}_{3} \times \mathrm{P}_{5}$ and $\mathrm{P}_{4} \times \mathrm{P}_{7}$ (Table 8).

It could be concluded that the previous cross combinations might be of interest in breeding programs towards the development of pure lines varieties for high biological, and grain yields/ plant under drought conditions.

Table 7. Estimates of specific combining ability effects for yield and its components 'at the combined analysis.

\begin{tabular}{|c|c|c|c|c|c|c|}
\hline $\begin{array}{c}\text { cross } \\
\text { combinatio } \\
\mathbf{n} \\
\end{array}$ & $\begin{array}{c}\text { plant } \\
\text { height } \\
(\mathbf{c m})\end{array}$ & $\begin{array}{c}\text { spike } \\
\text { length }(\mathrm{cm})\end{array}$ & $\begin{array}{c}\text { No. of } \\
\text { spikes /plant }\end{array}$ & $\begin{array}{c}1000 \text { kernel } \\
\text { weight }(g)\end{array}$ & $\begin{array}{c}\text { Biological } \\
\text { yield/plant (g) }\end{array}$ & $\begin{array}{c}\text { Grain } \\
\text { yield/plant } \\
\text { (g) } \\
\end{array}$ \\
\hline $\mathrm{P} 1 \times \mathrm{P} 2$ & 1.00 & -0.30 & $-8.00 * *$ & -0.01 & $-62.18 * *$ & $-4.97 *$ \\
\hline P1xP3 & -1.80 & -0.67 & $8.01 * *$ & -0.18 & $36.99 * *$ & -0.29 \\
\hline P1xP4 & $-4.14 * *$ & -0.98 & 2.76 & 0.39 & $37.66 * *$ & -2.70 \\
\hline P1xP5 & 0.57 & -0.13 & $3.97 *$ & -0.63 & $85.36 * *$ & $-14.40 * *$ \\
\hline P1xP6 & $5.17 * *$ & $1.24 *$ & -1.49 & 0.20 & $106.57 * *$ & $19.81 * *$ \\
\hline P1xP7 & $-4.02 * *$ & 0.54 & 1.96 & -0.17 & $-38.54 * *$ & $37.34 * *$ \\
\hline P2xP3 & $3.92 * *$ & $1.56^{* *}$ & $-6.71 * *$ & -0.31 & $-28.32 * *$ & 2.57 \\
\hline $\mathrm{P} 2 \mathrm{xP} 4$ & -1.42 & 0.24 & -0.83 & -0.28 & 1.04 & $-12.21 * *$ \\
\hline $\mathrm{P} 2 \mathrm{xP5}$ & -1.54 & -0.91 & 1.09 & -0.01 & 0.97 & $17.69 * *$ \\
\hline P2xP6 & 1.06 & $-1.37 *$ & 2.51 & 0.25 & 7.81 & -3.93 \\
\hline P2xP7 & -1.80 & 0.59 & 0.24 & -0.59 & $15.75 * *$ & $4.82 *$ \\
\hline $\mathrm{P} 3 \times \mathrm{P} 4$ & 0.95 & 1.54 & 1.31 & -0.04 & $-50.86 * *$ & 1.67 \\
\hline P3xP5 & 0.83 & 0.06 & 1.09 & -0.05 & $125.09 * *$ & $12.14 * *$ \\
\hline P3xP6 & -1.23 & $1.26^{*}$ & $4.96 * *$ & -0.08 & $10.66^{* *}$ & $-8.15^{* *}$ \\
\hline $\mathrm{P} 3 \mathrm{xP7}$ & $3.74 * *$ & -0.11 & $-7.59 * *$ & -0.62 & $-25.08 * *$ & $-26.12 * *$ \\
\hline
\end{tabular}




\begin{tabular}{|c|c|c|c|c|c|c|}
\hline \multicolumn{7}{|l|}{ Table 7 Cont. } \\
\hline $\mathrm{P} 4 \times \mathrm{P} 5$ & 1.16 & 0.74 & $-7.73 * *$ & 0.10 & $-18.50 * *$ & 0.12 \\
\hline $\mathrm{P} 4 \times \mathrm{P} 6$ & -0.24 & 0.11 & -2.42 & -0.29 & $-47.45 * *$ & 1.64 \\
\hline P4xP7 & $4.80 * *$ & 0.57 & -0.61 & 0.12 & $24.11 * *$ & $5.72 *$ \\
\hline $\mathrm{P} 5 \times \mathrm{P} 6$ & -1.18 & -0.37 & $-4.79 * *$ & 0.00 & $-43.74 * *$ & -2.78 \\
\hline P5xP7 & $-3.76 * *$ & $-1.57 * *$ & $11.28 * *$ & 0.34 & $-20.26 * *$ & $-5.19 *$ \\
\hline P6xP7 & 0.14 & 1.13 & -1.92 & 0.14 & 1.40 & -4.33 \\
\hline LSD5\%(sij) & 2.56 & 1.23 & 2.94 & $\mathrm{Ns}$ & 9.60 & 4.81 \\
\hline LSD1\%(sij) & 3.48 & 2.25 & 3.99 & $\mathrm{Ns}$ & 13.03 & 6.53 \\
\hline $\begin{array}{l}\text { LSD5\%(sij- } \\
\text { sik) }\end{array}$ & 2.20 & 1.48 & 2.52 & $\mathrm{Ns}$ & 8.23 & 4.13 \\
\hline $\begin{array}{l}\text { LSD1\%(sij- } \\
\text { sik) }\end{array}$ & 2.98 & 2.01 & 3.42 & $\mathrm{Ns}$ & 11.17 & 5.60 \\
\hline $\begin{array}{l}\text { LSD5\%(sij- } \\
\text { skL) }\end{array}$ & 0.78 & 0.52 & 0.89 & $\mathrm{Ns}$ & 2.91 & 1.46 \\
\hline $\begin{array}{l}\text { LSD1\%(sij- } \\
\text { skL) }\end{array}$ & 1.05 & 0.71 & 1.21 & Ns & 3.95 & 1.98 \\
\hline
\end{tabular}

$* \mathrm{p}<0.05 ; * * \mathrm{p}<0.01$

\section{References}

Abd El-Aty, M.A. and Y. S. Katta (2002).Genetic analysis and heterosis of grain yield and related traits in bread wheat (Triticumaestivum L.). J. Agric. Res. Tanta Univ., 28 (2): 287-300.

Al Saadoon A.W., A.A. EL Hosary, A. S. Sedhom, M.EL.M. EL-Badawy, A.A.A. Hosary (2017).Genetic analysis of diallel crosses in wheat under stress and normal irrigation treatments. Egypt. J. Plant Breed.21 (5): 279-292.

AL Sadoon A.W. , A.A. EL Hosary , S. A. Sedhom , M.EL.M. EL-Badawy and A.A.A. El Hosary (2018).Determination of Combining Ability and Genetic Diversity Using ISSR Markers to Evaluate the Genetic Variability in Wheat.Journal Tikrit Univ. For Agri. Sci. Vol. (18) special No. of The 7 th Scientific and 1st International Conference of Agricultural Researches, 10-11 April 2018. 67-80.

Al-Tamimi O.A., J.M.A. Al-Jbori and A.A.A. ElHosary (2020) Genetic analysis of $F 1$ cross in wheat (Triticumasetivum L.). Plant Archives 20: 413-4137.

Baker, R.J. (1978). Issues in diallel analysis. Crop Sci. 18: 533-536.

Chawla, H.S. and V.P. Gupta (1984).Index IndiaAgric. Calcutta Agric. Soc. Indian, 28(4): 261265.

Chowdhry, M. A.; M. Rafiq and K. Alam (1992).Genetic architecture of grain yield and certain other traits in bread wheat. Pakistan J Agric Res 13: 216-220.

El- Borhamy, H. S. (2000). Genetic studies on some quantitative characters in bread wheat (Triticumaestivum L.). Ph. D. Thesis Fac. Agric., Moshtohor, BenhaUniv.,

El-Hosary A.A. ; M. El. M. El-Badawy ; S.A.S Mehasen , A.A.A.; El-Hosary , T.A. ElAkkad and A. El-Fahdawy (2019) Genetic diversity among wheat genotypes using RAPD markers and its implication on genetic variability of diallel crosses. BIOSCIENCE RESEARCH, 2019 16(2): 1258-1266.

El-Hosary A.A., S.A. Omar and A.H.Wafaa (2009).Improving wheat production under drought conditions by using diallel crossing system. In: 6th International Plant Breeding Conference, Ismailia (Egypt).

El-Hosary A.A.A. and Gehan A. Nour El Deen (2015).Genetic analysis in the $F 1$ and $F 2$ wheat generations of diallel crosses. Egypt. J. Plant Breed. 19 (2): 355-373.

EL-Hosary, A.A.; M. E. M. EL-Badawy; A. K. Mustafa and M. H. EL-Shal (2012).Evaluation of diallel wheat crosses under drought tolerance .Egypt. J. Plant Breed. 16 (1): 19-40.

EL-Maghraby, M.A.; M. E. Moussa; N.S. Hana and H. A. Agrama (2005). Combining ability under drought stress relative to SSR diversity in common wheat.Euphytica. 141: 301-308.

El-Seidy, E. H. and A. A. Hamada (1997).Genetic analysis of diallel crosses in wheat under normal irrigation and drainage water conditions. Annals of Agric. Sc., Moshtohor, 35 (4) : 1915-1932.

El-Seidy, E. H. and A. A. Hamada (2000).Interaction of wheat genotypes $\times$ Water sources .Proc . 9 th conf. Agron. 1-2 Sept. Minufiya Univ., 17-34.

Farshadfar, E.; S. Mahjouriand M. Aghaee (2008). Detection of epistasis and estimation of additive and dominance components of genetic variation for drought tolerance in durum wheat. $\mathrm{J}$ BiolSci 8(3): 548-603.

Fathallah F.B., A. A. ElHosary, M. ELBadawy, A.A.A. ElHosary ,R. M. Esmail and Sherin A. Mahfouze (2020) Validation of simple sequence repeats (SSRs) linked to drought susceptibility index in diallel cross Wheat. 5th International Conference on Biotechnology Applications in Agriculture (ICBAA), Benha University, Hurghada, 8-11April 2020, Egypt. 215- 231. 
Gomaa, M. A.; M. N. M. El-Banna ; A. M.Gadalla ; E.E. Kandil and A.R.H. Ibrahim (2014). Heterosis, combining ability and drought susceptibility index in some crosses of bread wheat (Triticumaestivum L.) under water stress conditions . Middle- East j. Agric. Res., 3(2): 338-345.

Gomez, K.N. and A.A. Gomez (1984).Statistical Procedures for Agricultural Research.John.Wiley and Sons. Inc., New York, $2^{\text {nd }}$ ed.

Griffing, B. (1956). Concept of general and specific combining ability in relation to diallel crossing system. Aust. J. Biol. Sci.9: 463-493.

Iqbal, M.; A. Navabi; D. F. Salmon; R. C. Yang; B. M. Murdoch; S. S. Moore and D. Spaner (2007).Genetic analysis of flowering and maturity time in high latitude spring wheat .Euphytica 154 : 207-218.

Nouri, A.; A. Etminan; J. A. Teixeira da Silva and R. Mohammadi (2011).Assessment of yield, yield related traits and drought tolerance of durum wheat genotypes ( Triticumturjidumvar. durum Desf.). Aust J Crop Sci 5(1): 8-16.

Prasad, K.D., M.F. Haque and D.K. Ganguli (1998).Heterosis studies for yield and its components in bread wheat (Triticumaestivum L. ).Indian J. Genet. 58: 97-100.

Sprague. T. L. and A. Tatum (1942) General versus specific combining ability in single crosses of corn. J. AMSocAgron. 43:923-932

Steel, R. G. D. and J. H. Torrie (1980). Principles and Procedures of Statistics: A Biometrical Approach. McGraw Hill Book Co., Inc., New York, USA.

Topal, A.; C. Aydin; N. Akgiin and M. Babaoglu (2004).Diallel cross analysis in durum wheat (Triticum durum Desf.): identification of best parents for some kernel physical features. Field Crop Res 87(1): 1-12. 